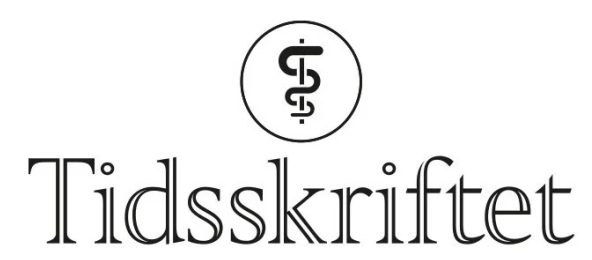

DEN NORSKE LEGEFORENING

\title{
Anfallsforebyggende legemidler, ikke antiepileptika
}

SPRÅKSPALTEN

\section{KARL O. NAKKEN}

karln@ous-hf.no

Karl O. Nakken er pensjonert nevrolog.

\section{ERIK SAETRE}

Erik Sætre er spesialist i nevrologi og overlege ved Spesialsykehuset for epilepsi.

\section{Termene antiepileptika, antikonvulsiva og refraktcr epilepsi er} upresise og bør erstattes av moderne betegnelser.

Medisinsk fagterminologi endres i takt med økt viten (11). Månesyke som betegnelse på epilepsi er for lengst forlatt. Pasientene er ikke spesielt anfallsutsatte ved fullmåne. Betegnelsen fallesyke er også forlatt. Vi vet nå at under halvparten av epileptiske anfall er forbundet med fall ( $\underline{2})$.

\section{Internasjonal utvikling}

Fagtermene vi bruker, bør være mest mulig presise og speile dagens kunnskap. Legemidler brukt mot epilepsi har lenge vært kalt antiepileptika. Denne betegnelsen gir inntrykk av at legemidlene motvirker epilepsiutvikling, epileptogenesen, men det gjør de ikke. De gir kun en symptomatisk, anfallsdempende effekt uten å påvirke selve epilepsien og epilepsiprognosen. De påvirker kun anfallsutviklingen, iktogenesen, i en allerede etablert epileptogen lesjon ved å svekke, forkorte eller i beste fall forhindre epileptiske anfall.

Internasjonalt har ledende epileptologer lenge ivret for å skifte ut termen antiepileptic drug (AED) med den mer korrekte antiseizure medicine (ASM) (3). At antiepileptic drug, og det norske antiepileptika, er godt innarbeidet, anses ikke som tilstrekkelig argument for å fortsette bruken.

\section{På norsk}


Hva skal vi kalle legemiddelgruppen antiseizure medicines på norsk? Antianfallsmedisiner virker litt oppstyltet. Etter en uformell spørrerunde blant legene ved Spesialsykehuset for epilepsi var det bred enighet om å bruke anfallsforebyggende legemidler (tabell 1). Denne betegnelsen gjør det lettere å formidle til pasientene at medikamentene bare demper anfallstendensen uten å kurere sykdommen.

\section{Tabell 1}

Engelske termer med forslag til norske oversettelser.

\begin{tabular}{|lll|}
\hline Engelsk & Norsk & Synonym \\
\hline Antiseizure medicines & Anfallsforebyggende legemidler & Anfallsdempende legemidler \\
\hline Drug resistant epilepsy & Legemiddelresistent epilepsi & Farmakoresistent epilepsi \\
\hline Refractory epilepsy & Vanskelig kontrollerbar epilepsi & Alvorlig epilepsi \\
\hline
\end{tabular}

I engelskordboka er den medisinske betydningen av seizure forklart som 'anfall, slag(tilfelle), attakk'. Sånn sett er både seizure på engelsk og anfall på norsk uspesifikke termer ettersom antiseizure og anfallsforebyggende ikke sier noe om hvilken type anfall det er snakk om. Selv om vi på norsk kan snakke om migreneanfall og raserianfall, vil likevel leseren neppe være i tvil om at anfall brukt i en artikkel om epilepsi dreier seg om epileptiske anfall.

I fagmiljøet er det viktig å skille mellom anfallsdempende legemidler og det man for tiden jakter intenst på, nemlig medikamenter som griper inn i epileptogenesen, såkalte antiepileptogene eller sykdomsmodifiserende legemidler.

\section{Flere forslag}

Epileptiske anfall er en samlebetegnelse på anfall som enten er ledd i en epilepsi, som er det hyppigste, eller om anfall som ikke er ledd i epilepsi, som for eksempel feberkramper eller abstinensanfall. I tråd med det engelske epileptic seizures bør vi på norsk bruke betegnelsen epileptiske anfall, ikke epilepsianfall. Dersom man skulle ha brukt termen epilepsianfall, burde den ha vært forbeholdt de tilfellene der anfallene er ledd i en sikker epilepsi.

Legemidler brukt mot epilepsi blir av og til kalt antikonvulsiva. Etter vårt skjønn bør vi slutte også med denne termen, fordi disse legemidlene reduserer tendensen til mange typer epileptiske anfall, ikke bare krampeanfall. Dessuten virker noen av dem, som etosuksimid, ikke mot krampeanfall i det hele tatt (4).

Rundt en tredel av pasientene med epilepsi oppnår ikke anfallskontroll med de legemidlene vi har nå (5). Om disse pasientenes epilepsi har det vært brukt flere termer, som refraktcer, intraktabel eller terapiresistent. Vi mener disse er uheldige ettersom de gir inntrykk av at epilepsien er upåvirkelig av enhver form for behandling. Det er feil. Noen av pasientene kan hjelpes med for eksempel kirurgisk behandling, vagusnervestimulering eller ketogen diett. Vårt forslag er at vi i stedet bruker betegnelsen legemiddelresistent epilepsi eller farmakoresistent epilepsi.

Dersom flere behandlingsmodaliteter i tillegg til legemidler ikke har hjulpet, foreslår vi å bruke vanskelig kontrollerbar epilepsi eller alvorlig epilepsi. Det innebærer at det er vanskelig, men ikke umulig å kontrollere sykdommen. Vi bør ikke ordlegge oss slik at vi fratar pasientene ethvert håp om bedring. 


\section{LITTERATUR}

1. Nylenna M. Ord og uttrykk som forsvinner. Tidsskr Nor Legeforen 2019; 139. doi: 10.4045/tidsskr.19.0007. [CrossRef]

2. Tuft M, Nakken KO. Epilepsi som stigma - ond, hellig eller gal? Tidsskr Nor Legeforen 2014; 134: 2328-31. [PubMed][CrossRef]

3. French JA, Perucca E. Time to start calling things by their own names? The case for antiseizure medicines. Epilepsy Curr 2020; 20: 69-72. [PubMed][CrossRef]

4. Gören MZ, Onat F. Ethosuximide: from bench to bedside. CNS Drug Rev 2007; 13: 224-39. [PubMed] [CrossRef]

5. Brodie MJ. Pharmacological treatment of drug-resistant epilepsy in adults: a practical guide. Curr Neurol Neurosci Rep 2016; 16: 82. [PubMed][CrossRef]

Publisert: 7. september 2020. Tidsskr Nor Legeforen. DOI: 10.4045/tidsskr.20.0536

(C) Tidsskrift for Den norske legeforening 2023. Lastet ned fra tidsskriftet.no 26. april 2023. 